\title{
ISTIHSAN; ANALISIS HISTORIS PEMIKIRAN IMAM AS-SYAFI'I
}

\author{
Oleh: \\ Jainuddin \\ jainuddin.ptais015@gmail.com \\ Dosen IAI Muhammadiyah Bima
}

\begin{abstract}
:
Imam Syafi'I rejected the concept of Istihsan based on his reason, if someone uses the Ihtihsan as his reason, so he has made a new syare'at. As known, Imam Syafi'I committed to use Al-qur'an, As-Sunnah, Ijma' and Qiyas as the mind of his construction thinking. It was not born suddenly, but influenced by other elements. Imam Syafi'I is the great Muslim Figure known by multidiscipline knowladge; he developed the Hizza's model in his thinking which influenced by shades of science at Madinah and Iraq. To know deeply, this research uses the historical-approach, it purposes to know more easy his thinking about Istihsan and how it was born. Besides, Imam Syafi'I was not rejected totally the concept of istihsan, but there are some reasons to receive it. Refer to it, Imam Syafi'I rejected the concept of istihsan because it was assumed using extra logically in Istimbat.
\end{abstract}

Keywords: Islamic Law, Imam Syafi'i, Istihsan.

\section{Pendahuluan}

Para ulama telah sepakat bahwa sumber hukum yang pertama dalam Islam adalah Al-Qur'an. Al-Qur'an sebagai kitab suci senantiasa digunakan untuk mengabsahkan perilaku, menjustifikasi tindakan peperangan, melandasi berbagai aspirasi, memlihara berbagai harapan dan memperkukuh identitas bersama. ${ }^{1}$ Dengan Al-Qur'an nabi Muhammad menyelesaikan persoalan-persoalan yang muncul dalam masyarakat pada waktu itu. Nampaknya segala persoalan di masyarakat ketika itu tidak bisa diselesaikan dengan wahyu disebabkan oleh sifat wahyu yang masih global dan tidak memberikan penjelasan persoalan secara terperinci. Dalam situasi yang seperti itu Nabi Muhammad Saw menyelesaikannya dengan pemikiran dan pendapatnya sendiri yang terkadang nabi Muhammad Saw juga melakukan musyarah dengan para sahabat yang kemudian disebut dengan Sunnah Rasul.

1 Mohammad Arkoun, Berbagai Pembacaan al-Qur'an, terj. Machasin (Jakarta: INIS, 1997), hlm. 9 
Pada saat Nabi Muhammad Saw masih hidup semua persoalan yang dihadapi umat dapat diselesaikan oleh Nabi Muhammad Saw. Tetapi ketika beliau sudah meninggal segala persoalan tersebut di rasa sulit untuk dicarikan jawabannya dalam alQur'an dan Sunnah Nabi Saw sehingga para sahabat melakukan ijtihad. ijtihad yang dilakukan dianggap tidak dapat diuji tentang kebenaran dan kesalahannya maka yang dilakukan adalah mengadakan ijma' (kesepakatan), sebab, putusan yang diambil secara ijma' akan lebih baik dibandingkan dengan yang dilakukan secara sendiri-sendiri.

Ketika wilayah Islam bertambah luas yang mengakibatkan terpencarnya para ulama di setiap wilayah-wilayah kekuasaan Islam yang baru maka ijma' pun tidak dapat diambil secara bulat. Pada situasi yang seperti ini para ulama cenderung untuk melakukan istinbath sendiri-sendiri yang berakibat pada lahirnya apa yang disebut dengan Qiyas, Istislah, 'Urf, istihsan, dan sebagainya.

Istihsan sebagai metode istimbath hukum masih menjadi perdebatan di kalangan para ulama tentang keabsahannya. Tidak semua ulama yang menolak istihsan sebagai metode istimbath hukum seperti Imam Hanafi dan Imam Maliki sedangkan yang menolak secara bulat dan tidak menjadikannya sebagai metode istimbath hukum yaitu Imam Hambali dan Imam Syafi'i. Sehingga metode Istihsan ini sebagian ulama mazhab ada yang menerima dan menolak. Imam Syafi'i mengatakan bahwa istihsan merupakan cara istimbath hukum dengan hawa nafsu dan mencari enaknya saja. ${ }^{2}$ Imam Syafi'i juga mengatakan bahwa ijtihad yang dilakukan dengan metode Istihsan adalah batal. ${ }^{3}$ Berdasarkan beberapa perbedaan pandangan tentang istihsan tersebut diatas, maka menarik untuk dikaji pemikiran Imam Syafi'i tentang istihsan.

\section{Sejarah Kehidupan Imam Syafi'i dan Pemikirannya}

Berdasarkan tarikh kelahiran Abu Abdullah Muhammad bin Idris asy-Syafi'i atau yang lebih dikenal dengan sebutan Imam Syafi'i, adalah pendiri mazhab Syafi'i. beliau dilahirkan di Ghaza (Palestina) pada tahun $105 \mathrm{H}$ atau bertepatan dengan 767 M. ${ }^{4}$ Silsilah beliau dari

\footnotetext{
${ }^{2}$ Mengenai hal itu beliau mengatakan "siapa yang melakukan istihsan berarti telah membuat syari'at"

${ }^{3}$ Imam Syafi'I mengatakan "semua ijtihad yang dilakukan para mujtahid tanpa melakukan penyandaran pada salah satu diantara kitab (al-Qur'an, Al-Sunnah, Atsar, Ijma' atau Qiyas, maka ijtihad yang demikian disebut istihsan, sebab para mujtahid telah menetapkan hukum berdasarkan apa yang baik (istihsan) menurut mereka, dan ijtihad yang dilakukan dengan cara demikian (istihsan) adalah batal". Lihat. Muhammad Abu Zahrah, Ushul al-Fiqh (Beirut: Dar al-Fikr al-'Arabi, 1958), h. 262

4 Ada perbedaan mengenai tempat Imam Syafi'I dilahirkan. Ada yang mengatakan bahwa beliau dilahirkan di Asqalan yaitu sebuah wilayah yang jauhnya
} 
ayah adalah Muhammad bin Idris bin Abbas bin Utsman bin Syafi'i bin Sa'ib bin Abdu Yazid bin Hasyim bin Abdul Muthalib bin Abdul Manaf. Sedangkan silsilah dari ibunya adalah Muhammad binti Fatimah bin Abdullah bin Al-Hasan bun Husain bin ali bin Abi Thalib.

Setelah ayah Imam Syafi'i meninggal, sekitar dua tahun kelahirannya, sang ibu membawanya ke Mekkah. Disana ia tumbuh besar dalam keadaan yatim. Sejak kecil Imam Syafi'i sangat cepat menghafal syair, pandai berbahasa arab dan sastra. Di Mekkah, Imam Syafi'i berguru Fiqh kepada mufti disana. Ketika ia berusia 15 tahun dia mulai senang mempelajari fiqh setelah ia menjadi tokoh dalam bahasa Arab dan Syairnya. Ia belajar fiqh dari para ulama fiqh yang ada di Mekkah. Kemudian ia belajar dari Dawud bin Abdurrahman Al-Atthar, juga belajar dari pamanya yang bernama Muhammad bin Ali bin Syafi'i, dan juga menimba ilmu dari sufyan bin Uyainah. Guru yang lainnya dalam fiqh ialah Abdurrahman bin Abi Bakr Al-Mulaiki, Sa'id bin salim, fudail bin al-Ayyadl dan masih banyak lagi yang lainnya. Dia pun semakin menonjol dalam bidang fiqh hanya dalam beberapa tahun sajaa duduk diberbagai halaqah ilmu para ulama fiqh sebagaimana tersebut diatas.

Keistimewaan lain Imam Syafi'i ialah menghafal Al-Quran ketika berusia lebih kurang Sembilan tahun di luar kepala. Selain itu juga Imam al-Syafi'i juga mempelajari ilmu agama lainnya, seperti ilmu hadits dan ilmu al-Qur'an. Untuk ilmu Hadits ia berguru pada ulama hadits pada masa itu yaitu Imam Sufyan bin Uyainah sedangkan untuk Ilmu Qur'an ia belajar kepada ulama besar Imam Ismail bin Qastani. ${ }^{5}$

Menurut Imam Syafi'i, qiyas hanya dapat digunakan dalam keadaan terpaksa yaitu dalam masalah mu'amalah (kemasyarakatan) yang tidak didapati nasnya secara pasti dan jelas di dalam al-Qur'an atau hadits Nabi atau tidak dijumpai dalam ijma' para sahabat. Qiyas sama sekali tidak dibenarkan dalam urusan ibadah. Dalam penggunaan qiyas, Imam Syafi'i menegaskan bahwa harus diperhatikan nas-nas alQur'an dan Sunnah yang telah ada. Ketika Imam Syafi'i tingga di Bagdad selama 2 tahun, atas wewenang yang diberikan oleh sang guru

dari Ghaza sekitar tiga kilometer dan tidak jauh dari Baitul Maqdis. Menurut AnNawawi pendapat yang termashur adalah beliau dilahirkan di Gaza.

5 Sebagian riwayat mengatakan bahwa karena kemahirannya di bidang ilmu fiqh inilah, maka al-Syafi'i diberi ijin oleh Muslim Khalid al-Zanji untuk memberi fatwa di masjid al-Haram selama lima belas tahun. Lebih lanjut tentang hal ini, lihat 'Abd al-Halim al-Jundi, Al-Imam al-Syafi'i: Nasir al-Sunnah wa Wadi' alUshul (Beirut: Dar a-Qalam, 1966), h. 31. Disamping itu pula Kesungguhan alSyafi' $i$ dalam mempelajari ilmu hadits ini tanpa kenal lelah. Meskipun ia dalam kondisi miskin dan tidak mampu, tetapi ia dengan tekun mencatat pelajarannya di atas kertaskertas bekas dan kantor-kantor pemenintah dan tulang-tulang. Pada usia sepuluh tahun, ia sudah membaca seluruh isi kitab al-Muwatta' karya Imam Malik dan pada usia lima belas tahun, ia telah menduduki kursi mufti di Mekah. (Lihat Tim Ensiklopedi Islam, op. cit., h. 327) 
muslim bin Khalid, seorang ulama besar yang menjadi mufti di mekkah. Ia mengeluarkan fatwa-fatwa selama tinggal di Baghdad, pendapat-pendapat Imam Syafi'i tersebut dinamakan qaul qadim. Ketika itu pengaruh mazhab Syafi'i mulai tersebar luas dikalangan masyarakat, kemudian untuk sementara waktu ia terpaksa meninggalkan Baghdad menuju Mekkah untuk memenuhi panggilan hati yang masih haus ilmu pengetahuan. ${ }^{6}$

Pada tahun 198 H. imam Syafi'i kembali ke Baghdad untuk merawat dan mengembangkan benih-benih mazhab yang telah ditebarkan, pada saat itulah pengaruhnya mengalami perkembangan pesat. Hampir tidak ada lapisan masyarakat Baghdad yang tidak tersentuh oleh roda pemikirannya, dan diantara pilar-pilar pendukung mazhab Imam Syafi'i yang masyhur adalah Ahmad bin Hambal (pendiri mazhab Hambali) al-Zafarani, Abu Sur, al-Karabisi, empat orang inilah yang tercatat sebagai periwayat qaul qadim yang tertuang dalam kitab al-hujjah.

Kemudian Imam Syafi'i mengembara ke negeri Mesir, di sana Imam Syafi'i meneliti dan menelaah kembali ketetapan-ketetapan fatwa-fatwanya selama Imam Syafi'i berada di Baghdad, dari hasil kajian mengulang yang pada akhirnya melahirkan istilah qaul jadid sebagaimana tertulis dalam kitab al-Umm, al-Imla, Mukhtasar Muzanni dan albuwaiti.7

Sebagai seorang ilmuwan yang multidisipliner, Imam Syafi'i memiliki banyak karya ilmiah. Berdasarkan riwayat Imam Abu Muhammad al-Hasan bin Muhammad al-Marwaziy seperti yang dikutip al Nawawi bahwa karya ilmiah imam Syafi'i mencapai 113 kitab tentang tafsir, fiqh, kesusastraan 'arab dan lainnya. ${ }^{8}$ Karya-karyanya terkenal dengan materi yang luas dan analisa yang dalam khususnya alRisalah dan al-Umm. Pertama, Al-Risalah merupakan kitab yang pertama yang lebih khusus membahas tentang ushul fiqh. Kitab ini dinamai alrisalah dikarenakan kitab ini di kirim oleh Imam Syafi'I dari Bagdad kepada Abd Al-Rahman bin Mahdi yang berada di Makkah. ${ }^{9}$ Kitab alRisalah al-Qadimah ditulis oleh Imam Syafi'i di Mekkah dan baru

\footnotetext{
${ }^{6}$ Khudari Beik, Tarikh at-Tasyri al islamiy, hlm. 253-254

${ }^{7}$ Sebenarnya kepergian imam syafi'I ke mesir atas permintaan wali negeri mesir 'Abbas bin Musa untuk memberikan pengajaran di masjid 'Amru bin Ash. Hal ini bagi imam syafi'I sangat berat, karena harus meninggalkan banyak murid di Baghdad sementara pengajaraan di mesir dilakukan siang hari di masjid dan malam hari di rumahnya. Ensiklopedi Islam, Cet. 3(Jakarta: PT Ikhtiar Baru, Van Houve 1994), hlm 328

8 Abi Zakariya Muhyidin al-Nawawi, Tahzib al-asma' wa al-lughat (Beirut: Dar al-Kutub al-Ilmiyah, hlm 53

${ }^{9}$ Atik Wartini, Hak Pendidikan Anak Dalam Keluarga Dalam Pandangan Imam Syafi'I dan Relevansinya Dengan Pendidikan Anak Usia Dini di Indonesia. dalam Jurnal Musawa: Jurnal Studi Gender dan Islam) hlm. 73
} 
dsempurnakan ketika di Baghdad kemudian di kirim oleh Ibnu al Mahdi. ${ }^{10}$ Kedua, kitab al-Hujjah kitab ini termasuk dalam qaul wadim dalam bidang fiqh dan furu', karena disusun oleh Imam Syafi'i ketika di Baghdad. Isi kitab ini secara umum di tujukan untuk menanggapi pendapat yang di kemukakan oleh ulama Iraq khususnya pendapat Muhammad bin al-Hasan.11

Meskipun dikenal sebagai imam besar, Imam Syafi'i sangat terbuka terhadap perbedaan pendapat. Imam Syafi'i mengatakan tentang mazhabnya "Jika sebuah hadits Shahih bertentangan dengan perkataanku, maka buanglah perkataanku di belakang tembok". Imam Syafi'i mengatakan, "ikutilah ahli hadits oleh kalian, karena mereka orang yang paling banyak benarnya." Selanjutnya dikatakan bahwa "semua perkataanku yang menyelisih hadits yang shahih maka ambillah hadits yang shahih dan janganlah taqlid kepadaku." Disamping itu, Imam Syafi'i menegaskan, "jika kalian dapati dalam kitabku sesuatu yang menyelisih sunnah Rasulullah shalallahu 'alaihi wassalam maka ucapkanlah sunnah Rasulullah dan tinggalkan ucapanku."

\section{Istihsan dalam Ushul Fiqh Imam Syafi'i}

Sebagaimana telah dijelaskan sebelumnya bahwa Imam Syafi'i merupakan salah seorang ulama yang menetang dengan keras istihsan sebagai metode dalam ber-istinbath hukum. Penolakannya itu tercermin dari perkataanya 'man istahsana faqad syara'a' (barang siapa yang menggunakan istihsan maka sesungguhnya ia telah membuat hukum). Bahkan dalam kitab 'Risalah'-nya, beliau menyatakan dengan tegas sebagai berikut:

"Allah tidak memberikan kepada seorang pun selain Rasulullah untuk menetapkan sesuatu hukum tanpa dalil dan tidak seorang pun pantas menetapkan berdasarkan apa yang dianggap baik (istihsan). Sesungguhnya menetapkan hukum dengan istihsan adalah membuat ketentuan baru yang tidak mempedomani ketentuan yang telah digariskan sebelumnya."12

Dari perkataan Imam Syafi'i di atas, dapat disimpulkan bahwa yang dimaksud dengan istihsan adalah pendapat yang tidak bersandarkan kepada keterangan (al-khabar) dari salah satu empat dalil syarak, yaitu al-Quran, sunnah, ijma' dan qiyas. Apabila seorang

10 Abu Zahrah, Al-Imam al-Syafi'I Hayatuhu wa Asruhu Ara'uhu wa fiqhuhu (Mesir: Dar Al-Fikr al-'Arabiyy, t.t.) hlm. 27

11 A. Nahrawi A.S, Al-Imam al-Syafi'I fi Mazahabih al-Qadim wa alJadid, di terbitkan oleh pengarangnya untuk kalangan terbatas , 1994, hlm. 712

12 Imam al-Syafi'i, al-Risalah (Mesir: Matba'ah Musthafa al-Babi alHalabi, 1940/1358 H), hlm. 25 
mujtahid memfatwakan suatu hukum dan hukum itu tidak diambil dari al-khabar itu secara lafal dan juga tidak diambil dari logikanya secara qiyas, serta tidak ada ijma' pada hukum tersebut, maka fatwa itu dinamakan istihsan, karena tidak bersandarkan kepada al-khabar baik secara (langsung kepada) nas maupun secara istinbath. Fatwa itu hanya dianggap baik oleh mujtahid itu dengan akalnya dan dengan kecenderungan perasaannya, tanpa berdalil kepada suatu aI-khabar dan tanpa mempertanggungkan kepada al-khabar itu.

Menurut Imam Syafi'i, ${ }^{13}$ haram bagi seseorang yang berpendapat dengan istihsan, apabila istihsan itu bertentangan dengan al-khabar. Sedang, al-khabar yang terdiri atas Kitab dan sunnah adalah sesuatu yang berharga yang diteliti maknanya oleh mujtahid untuk memperoleh pengertiannya yang benar. Mujtahid itu bisa memahami al-khabar dengan qiyas dan seorang pun tidak boleh mengemukakan pendapat kecuali dari segi ijtihad. Dan ijtihad adalah upaya mencari kebenaran. Maka dengan demikian tidak boleh seseorang mengatakan, "aku menganggap baik," tanpa melakukan qiyas.

Seandainya, qiyas boleh diingkari, maka boleh juga bagi orang yang bukan ahli ilmu berpendapat dengan sesuatu yang tidak ada nash dengan istihsan yang mereka gunakan. Padahal sebenarnya pendapat yang tidak berdasarkan kepada al-khabar dan qiyas tidak sah karena tidak bersumber kepada al-Quran, sunnah, dan qiyas. Banyak nash, baik al-Quran maupun hadits yang melarang berpendapat yang tidak disandarkan kepada al-khabar. Karena sesungguhnya apabila Nabi SAW menyuruh melakukan ijtihad, maka ijtihad selalu berdasarkan suatu tuntutan. Dan menuntut sesuatu harus berdasarkan dalil-dalil, sedangkan dalil-dalil itu adalah qiyas. Sedangkan dalam istihsan tidak terdapat qiyas.

Selanjutnya Imam al-Syafi'i memberikan contoh dengan mengatakan, bahwa seseorang yang tidak mengerti masalah harga seorang budak, maka tidak boleh dimintakan menetapkan harga seorang budak laki-laki atau harga seorang budak perempuan. Demikian juga kepada orang yang tidak mengerti masalah upah pekerja tidak boleh dimintakan menetapkan upah pekerja. Sebab, apabila ia menetapkan harga budak tidak sesuai dengan dalalat (petunjuk) harganya atau menetapkan upah pekerja tidak sesuai dengan dalalat upahnya, berarti ia bentindak sembarangan.

Oleh karena itu, menurutnya lebih lanjut, menyimpulkan halhal yang kecil seperti itu saja tidak boleh dilakukan dengan sembarangan, apalagi masalah halal dan haram yang merupakan ketentuan Allah maka tidak boleh ditetapkan secara sembarangan dan

${ }^{13}$ ibid., hlm. 503-505 
secara istihsan. Yang demikian, tidak lain daripada mencari enaknya saja (talazzuz).

Dengan demikian, maka selain Rasulullah tidak ada seorang pun yang berhak mengemukakan pendapat kecuali berdasarkan dalildalil yang telah disebutkan di atas. Orang tidak boleh berpendapat dengan "apa yang dianggapnya baik", karena pendapat dengan apa yang dianggapnya baik" adalah sesuatu yang dibuat-buatnya bukan berdasarkan tradisi atau contoh yang telah ada. ${ }^{14}$

Dari uraian di atas jelaslah bahwa Imam alSyafi'i menghubungkan istihsan dengan semua fatwa yang tidak disandarkan kepada al-khabar, baik secara langsung kepada nash maupun dengan cara menghubungkan kepada nash dengan cara qiyas. Atau dengan kata lain bahwa istihsan merupakan metode istinbath hukum yang tidak berdasarkan kepada al-Quran atau sunnah atau ijma' atau qiyas. Dengan demikian, maka tidak mengherankan kalau Imam alSyafi'i menolak istihsan sebagai dalil syarak dan Ia mengeritik keras istihsan tersebut.

Berkaitan dengan penolakannya terhadap istihsan ini, beliau mengemukakan beberapa dalil (argumen), sebagaimana tercermin dalam kitabnya al-Risalah dan al-Umm. Ia mengemukakan dalil-dalil dari al-Quran dan hadits, di antaranya: ${ }^{15}$

a. Surat al-Maidah (5): 3:

"Pada hari ini telah Kusempurnakan untuk kamu agamamu, dan telah Kucukupkan kepadamu nikmat-Ku, dan telah Kuridhai Islam itu jadi agama bagimu."

b. Surat al-Qiyamah (75): 36 yang berbunyi:

"Apakah manusia mengira, bahwa ia akan dibiarkan begitu saja (tanpa pertanggung jawaban)."

c. Surat al-Nahl (16): 89 yang berbunyi:

"Dan Kami turunkan kepadamu Al kitab (Al Quran) untuk menjelaskan segala sesuatu dan petunjuk serta rahmat dan kabar gembira bagi orang-orang yang berserah diri."

Sedangkan hadits yang dijadikan dalil (argumen) adalah sabda Nabi Muhammad SAW yang berbunyi:

“Aku tidak membiarkan sesuatu yang diperintahkan kamu oleh Allah kecuali aku juga sungguh-sungguh memerintahkan kamu dengannya, demikian juga aku tidak membiarkan sesuatu pun yang dilarang kamu oleh Allah - mengerjakannya - kecuali aku pun melarangnya".

\footnotetext{
${ }^{14}$ Ibid., hlm. 21

15 al-Syafi'i, al-Umm, Juz. VII (Beirut: Dar al-Fikr, t.th.), hlm. 314
} 
Menurut al-Syafiti, semua nash di atas menunjukkan bahwa Allah tidak membiarkan manusia begitu saja, tanpa pertanggungjawaban. Allah telah menyempurnakan agama dan nikmat-Nya serta menjadikan Al-Quran sebagai pemberi penjelasan terhadap segala sesuatu. Sekiranya seseorang dibolehkan mengemukakan pendapat tanpa berpedoman kepada al-Quran atau sunnah, atau ijma', atau qiyas, maka berarti boleh mengeluarkan pendapat yang bertentangan dengan khabar-Nya.

\section{Penolakan Imam al-Syafi'i terhadap Istihsan: Analisis Historis}

Imam Syafi'i hidup pada masa awal Bani 'Abbasiyah, yang mana ketika itu merupakan masa yang cerah bagi kajian-kajian hukum Islam secara sistematis. ${ }^{16}$ Pada waktu itu, terdapat tiga pembagian geografis yang besar dalam dunia Islam, dimana kegiatan-kegiatan hukum yang bebas terjadi, yaitu lrak, Hijaz dan Syria. ${ }^{17}$ https://rasail.wordpress.com/2012/05/25/157/ ftn48 Irak memiliki dua madhhab, yaitu madhhab Basrah dan Kufah, di mana perkembangan hukum di Kufah lebih baik daripada di Basrah. Begitujuga diHijazjuga memiliki dua pusat kegiatan hukum, yaitu Madinah dan Makkah.

Dari kedua tempat tersebut, Madinah lebih menonjol dan menjadi tolak ukur dalam perkembangan hukum di Hijaz. Sedangkan mazhab Syria, jarang tercatat dalam buku-buku teks awal. Meskipun demikian, kecenderungan hukum dan mazhab ini dapat diketahui dari tulisan-tulisan Abu Yusuf.

Mazhab Mesir juga tidak begitu terkenal dalam petapeta mazhab hukum awal, karena ia tidak mengembangkan pemikirannya sendiri. Sebagian ahli hukum Mesir mengikuti doktrin Irak dan sebagian lagi mengikuti doktrin Madinah. Nama al-Layth bin Sa'd (W.175 H) nampaknya merupakan figur menonjol di kalangan ahli hukum Mesir, ia memiliki penbedaan-perbedaan tertentu dengan Malik. Karena pada saat itu banyak bermunculan mazhabmazhab hukum di propinsi-propinsi Islam, maka di sini penulis akan menguraikan lebih lanjut tentang mazhab Madinah dan Kufah, sebab

16 Imam al-Syafi' $i$ lahir pada tahun $150 \mathrm{H}$, di mana pemerintahan Islam ketika itu berada dibawah kekuasaan Bani 'Abbisiyah. Pada tahun 145-193 H/763-809 M, Bani 'Abbasiyah mencapai masa keemasan di bawah Khalifah Harun alRasyid, yang terkenal dengan istilah "The Golden Age of the Abbasid Caliphate”. Lebih lanjut, lihat Hugh Kennedy, The Prophet and the Age of the Caflphates (New York : Longman, 1986), h. 133-135.

${ }^{17}$ Ahmad Hasaan, The Early Development of Islamic Jurisprudence, hlm. 
kedua mazhab ini merupakan mazhab yang terpenting dan sanggup bertahan lama di antara mazhab-mazhab yang lain.

Pada awal pemerintahan Abbasiyah, terdapat dua kecenderungan metode yurisprudensi. Pertama, dalam rangka memantapkan dan memadukan doktrin hukum, pemikiran menjadi sistematis, dan keberadaan $\mathrm{ra}^{\prime} y$ (pendapat murni) melahirkan metode deduksi-analogis (analogical deduction), yang disebut qiyas. Namun demikian, pertimbangan praktis seringkali mengharuskan orang meninggalkan cara berpikir analogis yang kaku. Kemudian, ditemukanlah metode berpikir baru yang lebih longgar, yang sebenarnya merupakan pengembangan dari metode qiyas. Metode ini disebut istihsan (menganggap baik).

Istihsan merupakan penyimpangan dari analogi dengan pertimbangan kepentingan publik, menguntungkan atau pertimbangan lainya yang sejenis. Delam metode ini, orang menerapkan suatu kriteria lain terhadap suatu kasus dan meninggalkan qiyas. Kecenderungan kedua delam yurisprudensi awal ialah makin diperkokohnya konsep tentang sunnah. ${ }^{18}$ Kini orang cenderung untuk mengklaim generasi pendahulu sebagai sumber dalam rangka mengokohkan suatu tradisi. Digambarkan bahwa doktrin yang dikedepankannya mempunyai akar yang merentangkan balik ke masa silam. Pada mulanya sumber ini tanpa nama, akan tetapi kemudian kecenderungan formalizme semakin meningkat, sehingga tidak cukup hanya menyebut bahwa ajaran tersebut mempunyai sumber, tanpa menyebut nama. ${ }^{19}$

Imam Malik misalnya, ketika membahas suatu masalah hukum, ia memulai diskusinya dengan mengutip hadits Nabi atau ajaran sahabat yang relevan, seperti masalah jual-beli hamba sahaya. Dokrin Madinah, yang berasal dari Imam Malik menetapkan bahwa "hak milik atas harta hamba tetap berada di tangan budak, bukan di tangan majikannya". Atas dasar ini, apabila si hamba dijual, maka hartanya ikut berpindah ke tangan pembeli bersama dirinya.

Sedangkan doktrin Kufah, mengajarkan bahwa seorang hamba, "tidak berhak" memiliki hartanya. Oleh karena itu, diri dan

${ }^{18}$ Sunnah adalah sebuah konsep perilaku, baik yang diterapkan kepada aksi-aksi fisik maupun kepada aksi-aksi mental. Selanjutnya sunnah ini tidak hanya tertuju kepada sebuah aksi sebagaimana adanya, tetapi selama aksi itu secara aktual berulang atau mungkin sekali dapat berulang kembali. Dengen perkataan lain, sebuah sunnah adalah sebuah hukum tingkah laku, baik yang terjadi sekali saja maupun yang terjadi berulangkali. Lebih lanjut, lihat Fazlur Rahman, Islamic Methodology in History (Karachi: Central Institute of Islamic Research, 1965), h. 1-2

${ }_{19}$ Umar misalnya acapkali digambarkan sebagai sumber asal sunnah di Madinah, sedangkan Ibnu Mas'ud memegang posisi serupa di Kufah. Dan akhirnya tak pelak lagi, sampailah orang pada tahap mengklaim Nabi Muhammad sebagai sumber ajarannya. 
hartanya merupakan dua barang yang terpisah keduanya dimiliki oleh majikannya. Maka tidaklah sah perpindahan dua barang itu sekaligus dengan satu harga, tanpa ditentukan nilainya masig-masing.

Ketika proses kristalisasi pendapat hukum dalam berbagai mazhab berjalan, muncullah Imam Syafi'i. Ia mempelajari karya-karya para pendahulunya, dengan mengadakan perjalanan panjang dari satu kota ke kota lain dan dari satu negeri ke negeri lain untuk mempelajari hadits dari sejumlah ahli hukum Irak dan Madinah, dan Ia berbeda pendapat dengan mereka dalam sejumlah persoalan.

Dalam masalah sistem hukum yang dipakai para pendahulunya, Imam al-Syafi'i menemukan sejumlah hal yang menyebabkan "ketidak-konsistenan" mereka dalam penalarannya. Dengan kata lain, ia melihat bahwa walaupun tradisi dari Rasulullah, para ahli hukum awal kadang-kadang lebih mengutamakan pendapat para sahabat atau mengabaikan tradisi jika ternyata berlawanan dengan praktek-praktek setempat.

Dalam masalah ini dapat dilihat pendapat Imam Malik tentang sebuah hadits mengenai "khiyar majelis". Hadits ini memberikan pada pihak-pihak yang terlibat dalam suatu kontak dagang, hak untuk memilih sebelum berpisah. Setelah menceriterakan hal ini, Malik berkata: "Kita tidak mempunyai batas (waktu) tertentu atau pun praktek yang mapan dalam masalah ini. Akan tetapi, dalam banyak kasus lain, Malik mengutip hadits dari Rasulullah dan mengikutinya.

Imam Syafi'i tanpa mengenal kompromi menyanggah pandangan bahwa pendapat seorang sahabat atau seorang tabi'in dapat lebih diutamakan daripada sebuah tradisi dari Rasulullah, jika keotentikan tradisi tersebut dapat dibuktikan. Ditunjukkan kepada Imam Syafi'i bahwa beberapa kesalahan mungkin sekali dapat terjadi dalam perjalanan penyampaian hadits, dan karena itu tak akan pernah dapat dipastikan keotentikannya secara sempurna.

Imam Syafi'i berargumen bahwa sebuah hadits dari Rasulullah diriwayatkan oleh para sahabat, sedangkan pendapat para sahabat diriwayatkan oleh para tabi'in. Oleh karena itu, ia bertanya mengapa riwayat dari sumber yang lebih tinggi (para sahabat) harus dianggap memiliki bobot yang lebih rendah daripada riwayat dari sumber yang lebih rendah (yakni para tabi'in). Maka, ia berpendapat bahwa kemenangan final (hujjah) adalah pada tradisi Rasulullah, dan bukan pada yang lain. ${ }^{20}$ Ia berpendapat bahwa tradisi Rasulullah adalah mencukupi sendiri dan tidak membutuhkan penguatan oleh praktek, sebagaimana pendapat mazhab-.mazhab awal. Ia menuduh mereka (mazhab-mazhab awal) telah mempelajari pengetahuan dan sumber yang lebih rendah, sedangkan ia memilih

${ }^{20}$ Imam as-Syafi' i, al-Umm, Juz. VII, op. cit., h. 179 
untuk mengambil dari sumber yang lebih tinggi (yakni tradisi dari Nabi). ${ }^{21}$

Imam Syafi'i merumuskan aturan-aturan yang terperinci untuk menimbang keabsahan tradisi-tradisi yang terisolir dan terputus (munqati'), karena hal itu merupakan usaha yang pertamatama untuk meninggalkan praktek-praktek yang telah berjalan lama, yang tidak menerima tradisi-tradisi tersebut. 22

Dengan demikian, Imam Syafi'i berusaha untuk merombak standar penilaian yang terdahulu mengenai keotentikan hadits. Dengan diterimanya secara bebas tradisi-tradisi yang terisolir (khabar alkhassah) dalam hukum oleh Imam al-Syafi'i, maka dengan gigih ia menyerang penggunaan $r a^{\prime} y$ yang tidak dibatasi, yang mana sebelum dia muncul, ra'y merupakan alat sederhana dan alamiah untuk menyelesaikan persoalan. Sikap Imam al-Syafi'i yang demikian ini juga berlaku pada penerapan istihsan oleh mazhab-mazhab awal, karena ia beranggapan bahwa istihsan merupakan penggunaan $r a^{\prime} y u$ secara bebas dan semau-maunya.

Dari pengertian yang dipahami oleh Syafi'i tentang istihsan, maka wajar saja kalau dia menolak mentah-mentah penggunaan istihsan. Para ulama Syafi'iyyah juga dengan keras menolak penggunaan istihsan sebagai dasar penetapan hukum dan bahkan menjadikannya sebagai salah satu dalil yang tertolak (al-adillah almardudah). Mengenai dasar yang dipakai oleh para pendukung istihsan, mereka memberikan pemahaman yang berbeda. Mengenai surat azZumar ayat 18 misalnya, ulama Syafi'iyyah mengatakan bahwa ayat tersebut tidak menunjukkan adanya istihsan, juga tidak menunjukkan kewajiban mengikuti perkataan yang terbaik. Surat az-Zumar ayat 55 juga tidak menunjukkan bahwa istihsan adalah dalil, apalagi menjadikannya sebagai yang terbaik. Sedangkan hadis Nabi Saw yang mereka kutip, mereka mengatakan bahwa hadis tersebut mengisyaratkan adanya ijma' kaum muslimin dan ijma' adalah hujjah yang berdasarkan pada dalil. Jadi hadits tersebut tidak berarti setiap orang yang memandang suatu urusan itu baik, maka baik menurut Allah SWT. Kalau pemahamannya seperti yang dilontarkan para pendukung istihsan, maka ketika kaum muslimin yang awam memandang suatu perkara itu baik, maka baik pula menurut Allah SWT. Inilah pemahaman yang seharusnya tidak ada dalam benak kaum muslimin.

Jika kita cermati pandangan para pendukung dan penolak kehujjah-an istihsan, maka akan kita temukan bahwa ada perbedaan mendasar tentang apa yang dimaksud dengan istihsan. Para Ulama yang menjadikan istihsan sebagai hujjah pada dasarnya tidak serta merta

\footnotetext{
${ }^{21}$ Ibid., h. 246

${ }^{22}$ Imam as-Syafi' i, al-Risalah, op. cit., h. 63-64
} 
memberikan kebebasan pada akal dan logika untuk menetapkan hukum tanpa batasan dan dasar yang jelas, bahkan mazhab Hanafi menjadikan istihsan sebagai bagian dari qiyas, dan qiyas merupakan salah satu metode penetapan hukum yang disepakati oleh sebagian besar ulama termasuk Syafi'i yang menolak penggunaan istihsan.

Dalam pembahasan tentang istihsan di atas, kita melihat bahwa istihsan diberlakukan pada masalah-masalah yang tidak ada nashnya sama sekali ataupun ada nash akan tetapi tidak mendukung terlaksananya maqasid asy-syari'ah. Sedangkan para ulama yang menolak istihsan pada dasarnya menolak istihsan sebagai langkah hatihati dan adanya kekhawatiran adanya penggunaan akal dan logika secara berlebihan sehingga mengesampingkan nash. Dan pandangan seperti ini pada dasarnya juga tidak disetujui oleh para pendukung istihsan. Artinya, mereka juga menolak penggunaan istihsan yang hanya berlandaskan pada logika dan akal tanpa ada dalil yang kuat. AlBazdawi dalam karyanya Kasyf al-Asrar (t.t: 104) mengatakan,

"Abu Hanifah terlalu mulia dan wara' untuk mengatakan sesuatu berdasarkan pada hawa nafsunya atau melakukan sebuah amal berdasarkan istihsan padahal ada dalil syar'inya."

Ini juga diungkapkan oleh al-Qaffal dan Ibn as-Sam'ani yang bermadzhab Syafi'i, mereka mengatakan;

"Apabila yang dimaksud dengan istihsan adalah apa yang dibahas dalam ushul (fiqh) dengan berbagai maknanya, maka itu adalah baik karena terdapat argumentasi untuk pemakaiannya. Kami (Syafi'iyyah) tidak mengingkarinya dan juga memakainya. Akan tetapi jika yang dimaksud dengan istihsan adalah menganggap buruk atau baik sesuatu dengan akal tanpa dalil, maka itulah yang kami tolak." 23

Hal ini menunjukkan bahwa perbedaan mengenai kehujjahan istihsan hanya bersifat redaksional atau lafzi, bukan pada hakekat istihsan secara istilah. Al-Buthi mengatakan bahwa keinkaran Syafi'i pada istihsan bukan dari sisi dijadikannya istihsan sebagai dalil yang mandiri, akan tetapi sebenarnya pada penggunaan ungkapan yang tidak tepat dalam mendefinisikannya. Ini diperkuat oleh kenyataan bahwa Syafi'i dalam beberapa kesempatan juga menggunakan istihsan. Misalnya beliau mengatakan dalam masalah mut'ah (pemberian pada wanita setelah ditalak): "Saya tidak mengetahui kadar tertentu (yang harus dipenuhi) dalam pemberian mut'ah', akan tetapi saya memandang lebih baik (Istihsan) jika kadarnya 30 dirham" Dalam masalah perpanjang masa syuf'ah, beliau mengatakan: "Saya

23 Asy-Syaukani, Ad-Durarul Bahiyyah fil Masa'ilil Fi’iqhiyah. (1 jilid), sebuah kitab fiqih ringkas. hlm. 74 
menganggap baik (astahsinu) masa syuf'ah adalah 3 hari" Ketika beliau ditanya tentang seorang pencuri yang menyodorkan tangan kirinya (untuk dipotong) padahal tangan yang harus dipotong adalah tangan kanan, maka beliau berkata: "Qiyas mengharuskan dipotong tangan kanannya, akan tetapi istihsan menghendaki tangan kanannya tidak dipotong." 24

\section{Simpulan}

Dari pembahasan di atas pada dasarnya Imam Syafi'i merupakan sosok ulama yang sudah meletakkan prinsip dasar dalam ilmu ushul fiqh. Imam Syafi'i merupakan sosok ilmuwan yang multidisipliner yang mampu menggabungkan konsep pemikiran Hizaz dan Iraq yang memiliki pengaruh pada masa itu. Metode istimbath hukum Imam Syafi'i menggunakan empat prinsip dasar yaitu al-Qur'an, Sunnah, ijma' dan Qiyas. Imam Syafi'i menolak penggunaan Istihsan sebagai langkah hati-hati dan adanya kekhawatiran penggunaan akal dan logika secara berlebihan sehingga mengesampingkan nash. Akan tetapi pada masalah-masalah tertentu di temukan juga bahwa Imam Syafi'i juga terkadang menggunakan Istihsan pada beberapa masalah seperti masalah mut'ah. Penggunaan istihsan oleh Imam Syafi'i dianggap sebagai penggunaan nalar dalam metode Istimbath hukum secara berlebihan sebab Imam Syafi'I senantiasa menempatkan empat prinsip dasar sebagai yang utama dalam istimbath hukum. Bagi Imam Syafi'i penempatan nalar dalam istimbath hukum pada posisi yang sangat rendah dari pada wahyu Allah, sementara Qiyas senantiasa merujuk pada al-Qur' an, Sunnah, dan 'Ijma para ulama.

\section{Daftar Pustaka}

Asy-Syurbasi, Ahmad, 2011, Sejarah dan Biografi Empat Mazhab, Jakarta: Amzah Rahmah I.

Doi, 2002, Penjelasan Lengkap Hukum-Hukum Allah (Syari'ah). Jakarta: PT. Raja Grafindo Persada

Wahban, az-Zuhali, 2007. Figh Islam Wa Adillatuhu 1, Damaskus: Darul Fikr Fariz,

Abu Zahrah, Muhammad, 2007. Imam Syafi'i: Biografi dan Pemikirannya, Jakarta: Lentera

Arkoun, Mohammad, 1997. Berbagai Pembacaan al-Qur'an, terj. Machasin, Jakarta: INIS,),

Abu Zahrah, Muhammad, 1958. Ushul al-Figh, Beirut: Dar al-Fikr al'Arabi

${ }^{24}$ Ar-Razi, Fakhruddin Muhammad bin 'Amr, 1400 H, al-Mahsul fi 'Ilm al-Usul, (Riyad: Universitas Islam Imam Muhammad bin Sa’ud). Hlm. 172-173 
al-Jundi, 'Abd al-Halim, 1966. Al-Imam Imam al-Syafi'i: Nasir al-Sunnah wa Wadi' al-Ushul, Beirut: Dar a-Qalam

Muhyidin al-Nawawi, Abi Zakariya, t.t. Tahzib al-asma' wa al-lughat, Beirut: Dar al-Kutub al-Ilmiyah

Wartini, Atik, 2015. Hak Pendidikan Anak Dalam Keluarga Dalam Pandangan Imam Syafi'i dan Relevansinya Dengan Pendidikan Anak Usia Dini di Indonesia. dalam Jurnal Musawa: Jurnal Studi Gender dan Islam)

Zahrah, Abu, t.t. Al-Imam Imam al-Syafi'i Hayatuhu wa Asruhu Ara'uhu wa fighuhu, Mesir: Dar Al-Fikr al-'Arabiyy

A.S, A. Nahrawi, 1994. Al-Imam Imam al-Syafi'i fi Mazahabih al-Qadim wa al-Jadid

al-Syafi'i, al-Risalah, Mesir: Matba'ah Musthafa al-Babi al-Halabi, $1940 / 1358 \mathrm{H}$

al-Syafi'i, al-Umm, Juz. VII, Beirut: Dar al-Fikr, t.th.

Kennedy, Hugh, 1986. The Prophet and the Age of the Caflphates, New York: Longman

Hasan, Ahmad, The Early Development of Islamic Jurisprudence,

Rahman, Fazlur, 1965. Islamic Methodology in History, Karachi: Central Institute of Islamic Research

Asy-Syaukani, Ad-Durarul Bahiyyah fil Masa'ilil Fi'iqhiyah. (1 jilid), sebuah kitab fiqih ringkas.

Ar-Razi, t.t. Fakhruddin Muhammad bin 'Amr, 1400 H, al-Mahsul fi 'Ilm alUsul, Riyad: Universitas Islam Imam Muhammad bin Sa'ud

Tim Ensiklopedi Islam, 1993. Ensiklopedi Islam, Jakarta : Ichtiar Baru Van Haeve.

Usman, Iskandar, 1994. Istihsan dan Pembaharuan Hukum Islam, Jakarta: Rajawali Pers.

Abu Zaid, Farouq, 1986. Syafii: Imam kaum Moderat dalam Hukum Islam: Antata Tradisionalis dan Modernis, Jakazta: P3M.

Al-Shiddieqy, Hasbi, 1988. Falsafah Hukum Islam, Jakarta: Bulan Bintang. J.. Brill's, E., 1987, First Encyclopedia of Islam 1913-1936, New York : E. J. Brill's.

Harun, Nasrun, 1996. Ushul Figh, Jakarta: Logos. 